\title{
ORGANIZATIONAL CULTURE IN THE HOSPITALITY INDUSTRY A BIBLIOMETRIC ANALYSIS AND SYSTEMATIC LITERATURE REVIEW
}

Jose Efren Leyva-Duarte Universidad Autônoma de Occidente, México

E-mail: iq.leyva.duarte.e@gmail.com

Maria Teresa de la Garza Carranza Tecnológico de Celaya, Instituto Politécnico Nacional, México E-mail: teresa.garza@itcelaya.edu.mx

José de Jesús Chávez Martínez Universidad Autônoma de Occidente, México E-mail: jojecham@hotmail.com

Francisco Javier Pinedo-de-Anda Universidad Autônoma de Occidente, México E-mail: fjpinedo@hotmail.com

Juan Cayetano Niebla Zatarain Universidad Autônoma de Occidente, México E-mail: juan.niebla@udo.mx

José Porfirio González Farías Tecnológico de Celaya, Instituto Politécnico Nacional, México E-mail: porfirio.gonzalez@itcelaya.edu.mx

Submission: 6/27/2019

Revision: 9/18/2019

Accept: 10/2/2019

\section{ABSTRACT}

Hospitality Industry has a particular context, it is broadly competitive, and in permanent change. An organizational culture can improve the results of different organizations. This study evaluates the organizational culture research in the field of the hospitality industry to obtain an understanding of its actual situation and future. The study used bibliometric analysis and systematic literature review to examine publications of five journals about hospitality in the Web of Science database, from 1980 to April 2019. Findings indicate that hotels are the main field of research of the hospitality industry, and the quantitative methodology approach is the most used. Moreover, it shows three paths of recent research for future analysis. 
DOI: 10.14807/ijmp.v11i4.1089

Keywords: Organizational Culture, Hospitality Industry, Hospitality Management, Bibliometric Analysis

\section{INTRODUCTION}

Today, the phenomenon of globalization, the opening of the market, and the growing customers' demand are requirements of competition that companies in the world must face. A select context of the industry in the world is the Hospitality Industry (HI). This industry is broadly competitive, and it is in permanent change. Hospitality Industry uses as a primary strategy to give appropriate service for guests and customers.

The hospitality industry is formed by enterprises that provide lodging, food, and drinks, and meetings for tourists, travelers, and for the residents of the locality where these enterprises are installed. The HI includes businesses such as hotels, restaurants, events, timeshare for tourists, clubs, institutional food services, and assisted living facilities that are businesses exclusively for residents (PIZAM, 2009).

In the hospitality industry, Organizational Culture (OC) is a scarce topic analyzed. Today, more than six thousands of research publications about OC have been published in the Web of Science database. However, a few publications have a relationship with the HI. The publications have been done taking into different context of the industry (building, technology, manufacturing, hospitality) and different methodology approach (quantitative, qualitative, and a mixed one). The analysis of diverse publications shows topics widespread related to OC, for example, performance, leadership, efficacy, market orientation (LEYVA-DUARTE et al., 2019).

On the other hand, organizational culture is associated with different improvements in outputs of the organizations where it has been analyzed, although if the OC is not adequate to the context, OC will not produce useful outputs (GAVRIC; SORMAZ; ILIC, 2016). However, OC could be used to improve the strategy of the HI, customer service. Hotels and restaurant are the focus of the research in the HI. Here, OC has been a scarce topic studied by the researches.

Consequently, the research analyzes the publications about organizational culture in the hospitality industry. Therefore, the research uses the Web of Science database as providing useful information on scientific research publications of organizational culture in the hospitality industry. In conclusion, our objective is to provide information about organizational culture paths for future studies and show it for interested researchers. 
DOI: 10.14807/ijmp.v11i4.1089

The article is organized in the next sections: section two will present a framework of reference for organizational culture in the hospitality industry; the methodological approach used in this research is shown in section three; section four exposes the results from the bibliometric analysis and the clusters existing in the literature; section five presents a systematic literature review of each cluster. Finally, conclusions are drawn, and future research directions are identified.

\section{LITERATURE REVIEW}

\subsection{Hospitality industry and organizational culture}

Hospitality is a concept that can be defined as an organizational culture that develops inside the organization, and this culture identifies the organization (PIZAM, 2018). The HI has a unique and specific culture when it is compared to other industries (DAWSON; ABBOTT; SHOEMAKER, 2011). HI is an industry that is formed by companies that offer lodging, food, and drinks, as well as meetings for tourists, travelers and for the residents of the locality where they are installed (PIZAM, 2009).

In another hand, Barrows; Powers; Reynolds (2012) mention that hotels and restaurants, as well as many other types of operations that offer shelter and/or food and entertainment to people away from home, making up the HI. Barrows et al. do not include in their definition to residents of the locality. The hospitality industry has its unique features; an example is the front-line employees, they do deliver physical products but also intangible products such as manners and experiences (KAO; TSAUR; WU, 2016).

Due to the growing competition on a global level, the hospitality industry needs to manage its internal operations and focus on raising service quality and reducing costs (VIJ, 2016). Several topics have been in the context of HI to improve the results of the enterprises, for instance, service, leadership, total quality service, empowerment, and so.

Service is a vital aspect of the HI (GJURASIC; LONCARIC, 2018). Excellent service influences a guest's decision to return to the hotel in this industry (GJURASIC; LONCARIC, 2018), the service quality perceptions are formed during production, delivery and consumption processes (KAO et al., 2016). Support and cooperation among hotel employees are critical factors at improving service quality (GJURASIC; LONCARIC, 2018). Total Quality Service (TQS) is a concept that organizations of the hospitality industry and tourism are embracing, this is to do TQS produce a good impact on the development of national hospitality sector (SINGH, 2015). 
DOI: 10.14807/ijmp.v11i4.1089

Therefore, unlike traditional produce-oriented service quality perceptions, it is supposed that managing total quality experiences should be found in the organizational culture of customer delight (KAO et al., 2016). Ensuring the generation of customer satisfaction and delight can promote customer loyalty because $\mathrm{HI}$ is in a constant change and demand more than a customer satisfaction-style management (KIM; VOGT; KNUTSON, 2015).

One of the essential strengths of the hospitality and tourism industry are human resources (KUSLUVAN et al., 2010). The complexity of managing the experiences of the guests is a feature of the hospitality industry, which makes the human resource managers of the companies in this industry became forced to find new techniques to manage the relationship with employees and guests (AZIC, 2017).

Some studies have analyzed how employee performance can be managed to improve the organizational bottom line (KUSLUVAN et al., 2010). A good fit between OC and person plays a significant role in predicting employee creativity (HON; LEUNG, 2011). Promoting service innovation and knowledge management have the potential to improve organizational performance and to achieve strategic goals for the HI (KASEMSAP; SOOD, 2017).

Through leadership competency and organizational culture, the hotels can react quickly to the needs of the customers. Then, responsiveness would enhance hotel revenue (ASREE; ZAIN; RAZALLI, 2010). In HI, a CEO focus on servant leadership improves positively firm performance through the service climate (HUANG et al., 2016). Managers need to understand the importance of not only customer satisfaction, but also customer loyalty is indirectly driven by the delight (KIM et al., 2015). An effective manager in the HI must keep in mind these three objectives: (1) making the guest welcome personally, (2) making things work for the guest, and (3) making sure that the operation will continue to provide service and meet its budget (BARROWS et al., 2012).

Is essential for organizations of the hospitality industry to learn that empowering employees to enhance their performance requires a shift in organizational culture (KRUJA; HA; DRISHTI; OELFKE, 2016). Moreover, empowering employees allows them to identify customer needs and implement solutions as one way to satisfy customers (CHIANG; JANG, 2008).

Three significant predictors of empowerment in the HI are self-management, work environment, and leadership (KRUJA et al., 2016). In the enterprises of hospitality, 
DOI: 10.14807/ijmp.v11i4.1089

empowerment is somewhat that makes feel useful to the employees about themselves and their jobs assigned (KRUJA et al., 2016).

Thus, the hospitality industry has a unique and specific organizational culture (DAWSON et al., 2011; BAVIK, 2016b). OC culture is not an overall yield studied in enterprises of HI. Some researchers have done variety of works about OC and its relationship with diverse topics in HI, for instance: Pizam (2018) defines hospitality culture as a system of shared norms, values, beliefs, traditions, and expectations whose ultimate goal is to provide exceptional service and memorable experiences to all the organization's stakeholders.

Dawson et al. (2011) built a scale to identify the variables of hospitality culture. This scale allows to know constructs included within the organizational hospitality culture: management principles, customer relationships, job variety, job satisfaction, principles, leadership, risk taker, accuracy, and composure.

Asree et al. (2010) analyzed the impact of leadership competency and OC on the responsiveness and the performance in hotels. They found positive relationships between OC and leadership with responsiveness, whereas responsiveness generated a positive relationship with hotel revenue.

In their research, Chen (2013) studied the relationship between how the organizational culture and leadership style affects the internal service quality in hotels in Taiwan. In this research, a questionnaire was applied to scholars, hotel managers and personnel of five hotels in Taipei, and the results indicated that organizational cultures and leadership styles have a significant influence on internal service quality.

In short, the role played for organizational culture in enterprises of the hospitality industry is not well defined. Organizational culture, specifically, as it relates to the hospitality industry, is also a research area that has remained relatively unexplored (BAVIK, 2016b). The questions are: what are the main topics associated with organizational culture in the hospitality industry?, and what is the intellectual structure of emerging literature on organizational culture in the hospitality industry?

Therefore, through of bibliometric analysis and a systematic literature review, this article has the aim to provide useful information on scientific research publications of organizational culture in the hospitality industry, identifying trend topics and new research field about this subject for researchers interested. 
ISSN: 2236-269X

DOI: 10.14807/ijmp.v11i4.1089

\section{METHODOLOGY}

The Web of Science Core Collection (WoS) is a widely used database. It was selected for this research because this database has been used in the previous bibliometric analysis in other areas. (LEYVA-DUARTE et al. (2019); CAPUTO et al., 2018; MASCARENHAS et al., 2017; MERIGO; YANG, 2017)

Web of Science Core Collection database includes six citation indexes: Science Citation Index Expanded (SCI-EXPANDED), Social Sciences Citation Index (SSCI), Arts \& Humanities Citation Index (A \& HCI), Book Citation Index-Science (BKCIS), Book Citation Index- Social Sciences \& Humanities (BKCI-SSH), Emerging Sources Citation Index (ESCI).

The research method consisted of four steps:

Step 1. The search in the database was done in three stages (see figure 1).

1) The phrase "Organizational Culture" used in the section of search in the WoS database. Here, a search by topic into the Web of Science database was select. The search by topic includes the following fields to search for a record of the database: title, abstract, keywords of the author, and keywords plus. The search in WoS obtained 6540 publications about the topic. These publications were published in 2418 journals.

2) A specific search in the complete list of 2418 journal was done. Using the criterion of selection of journals, in its name should include the word "Hospitality," five journals were selected because they met the selection criteria.

3) The criteria of selection of journal allowed a refined search to take into only the journals previously identified. Here, information about publications was obtained, and it was used for the present revision. An analysis of the abstract of the publication allowed to identifies two publication without a relationship to the topic. Thus, 43 publications were used to the present research. The search was done on April 30, 2019, and the range of time from 1980 to April 2019.

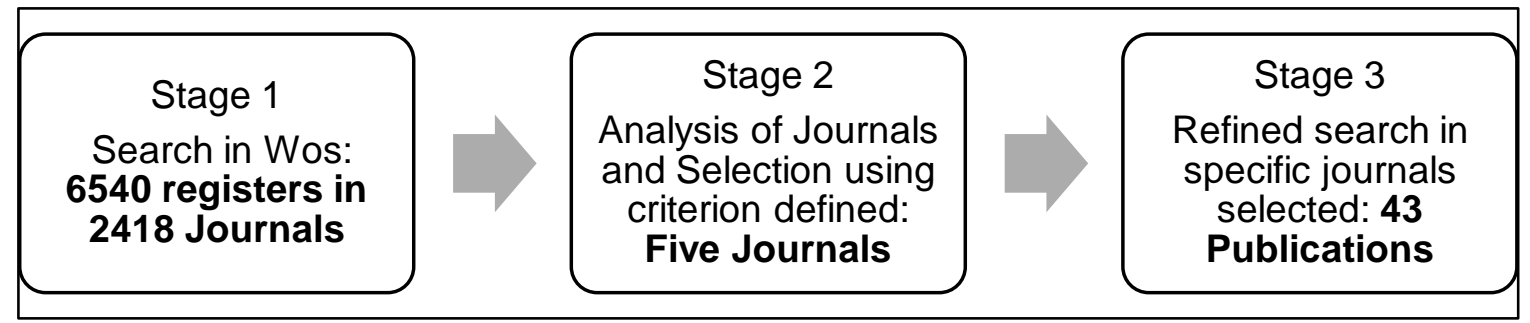

Figure 1: Search process used in WoS 
DOI: 10.14807/ijmp.v11i4.1089

Step 2. A bibliometric analysis using two specific indicators, co-occurrences of keywords and bibliographic coupling of publications was done. For this, the research used VOSviewer Version 1.6.9 software. Here, a detailed analysis was done on the information that WoS provided to facilitate the understanding of the topic. VOSviewer is a software that was developed for constructing and viewing bibliometric network maps. VOSviewer can, for example, be used to get maps of authors or journals based on co-citation data or to get maps of keywords based on co-occurrence data (VAN ECK; WALTMAN, 2010)

Step 3. For this research, the indicators of co-occurrences of Keywords and bibliographic coupling. Keywords analysis permitted to obtain the principal's topics associated with organizational culture and respond to; what are the topics associated with a particular line of research? (ZUPIC; CATER, 2015). Bibliographic coupling was used due to its ability to answer the following questions: 1 . "What is the intellectual structure of recent literature? 2. How does the intellectual structure of the research stream reflect the richness of the theoretical approaches?” (ZUPIC; CATER, 2015).

Step 4. In this step, the systematic literature review was done. It considered the articles involved in the network map of bibliographic coupling. The aim to explain what is happened with the research of organizational culture in the context of the Hospitality Industry was clarified.

\section{RESULTS}

In the first process of search in the Web of Science Core Collection, a total of 45 publications were obtained for this analysis in five leading journals. Table 1 shown the list of five journals selected by this analysis and the number of publications on organizational culture. Here, International Journal of Hospitality Management is the journal where organizational culture has been a topic widely taking into by the researchers. A review of abstracts identified two publications with less related to the topic, and these publications were excluded from the study

Table 1: Total of publications by a journal about Organizational Culture

\begin{tabular}{lc}
\hline Journal & Publications \\
\hline International Journal of Hospitality Management & 21 \\
International Journal of Contemporary Hospitality Management & 11 \\
Cornell Hospitality Quarterly & 5 \\
Journal of Hospitality And Tourism Management & 4 \\
Journal of Hospitality \& Tourism Research & 4 \\
\hline
\end{tabular}


ISSN: 2236-269X

DOI: 10.14807/ijmp.v11i4.1089

In table 2 present the 43 publications by journal, here include authors and year of publication and name of the publication. Moreover, it is shown the type of publications (article, review), the approach methodology (qualitative, quantitative o mixed), and the type of hospitality industry (Hotel o restaurant, other) where the research was done.

Table 2: Publications about organizational culture in five journals (Web of Science 1980April 2019)

\begin{tabular}{|c|c|c|c|c|}
\hline & Publication & $\begin{array}{c}\text { Type of } \\
\text { publication }\end{array}$ & $\begin{array}{c}\text { Approach } \\
\text { Methodology }\end{array}$ & Industry \\
\hline Authors: & (SUN et al., 2019) & & & \\
\hline Title: & $\begin{array}{l}\text { Impact of cultural values on technology acceptance } \\
\text { and technology readiness }\end{array}$ & Article & Quantitative & Hotel \\
\hline Authors: & (WANG; RYAN; YANG, 2019) & & & \\
\hline Title: & $\begin{array}{l}\text { Employee brand love and love behaviors: perspectives } \\
\text { of social exchange and rational choice }\end{array}$ & Article & Quantitative & Hotels \\
\hline Authors: & (PIZAM; TASCI, 2019) & \multicolumn{2}{|c|}{ Review } & \\
\hline Title: & $\begin{array}{l}\text { Experienscape: expanding the concept of servicescape } \\
\text { with a multi-stakeholder and multi-disciplinary } \\
\text { approach (invited paper for 'luminaries' special issue } \\
\text { of international journal of hospitality management) }\end{array}$ & & & \\
\hline Authors: & (PIZAM, 2018) & \multicolumn{2}{|c|}{ Editorial Note } & \\
\hline Title: & Hospitality as an organizational culture & & & \\
\hline Authors: & $\begin{array}{l}\text { (REYES-SANTIAGO; SANCHEZ-MEDINA;DIAZ- } \\
\text { PICHARDO, 2017) }\end{array}$ & Article & Quantitative & Hotels \\
\hline Title: & $\begin{array}{l}\text { Eco-Innovation and organizational culture in the hotel } \\
\text { industry }\end{array}$ & & & \\
\hline Authors: & $\begin{array}{l}\text { (NAZARIAN et al., 2017) } \\
\text { Influence of national culture and balanced }\end{array}$ & Article & Quantitative & Hotels \\
\hline Title: & $\begin{array}{l}\text { organizational culture on the hotel industry's } \\
\text { performance }\end{array}$ & & & \\
\hline Authors: & (ERHARDT, MARTIN-RIOS; HECKSCHER, 2016) & Article & Qualitative & Restaurants \\
\hline Title: & $\begin{array}{l}\text { Am I doing the right thing? Unpacking workplace } \\
\text { rituals as mechanisms for strong organizational culture }\end{array}$ & & & \\
\hline Authors: & (BAVIK, 2016) & Article & Mixed & Hotels \\
\hline Title: & $\begin{array}{l}\text { Developing a new hospitality industry organizational } \\
\text { culture scale }\end{array}$ & & & \\
\hline Authors: & (KAO et al., 2016) & Article & Qualitative & Hotels \\
\hline Title: & $\begin{array}{l}\text { Organizational culture on customer delight in the } \\
\text { hospitality industry }\end{array}$ & & & \\
\hline Authors: & (CHANG; MA, 2015) & Article & Qualitative & Hotels \\
\hline Title: & $\begin{array}{l}\text { Managing the service brand value of the hotel industry } \\
\text { in an emerging market }\end{array}$ & & & \\
\hline Authors: & (CHEN, 2013) & Article & Quantitative & Hotels \\
\hline Title: & $\begin{array}{l}\text { Factors influencing internal service quality at } \\
\text { international tourist hotels }\end{array}$ & & & \\
\hline Authors: & (ZHAO; MATTILA, 2013) & Article & Quantitative & Hotels \\
\hline Title: & $\begin{array}{l}\text { Examining the spillover effect of frontline employees' } \\
\text { work-family conflict on their affective work attitudes } \\
\text { and customer satisfaction }\end{array}$ & & & \\
\hline Authors: & (HWANG; KIM; HYUN, 2013) & Article & Quantitative & Restaurants \\
\hline
\end{tabular}


The role of server-patron mutual disclosure in the

Title: formation of rapport with and revisit intentions of patrons at full-service restaurants: the moderating roles of marital status and educational level

Authors: (CHOUDHURY; MCINTOSH, 2013)

Retaining students as employees: owner-operated

Title: small hospitality businesses in a university town in New Zealand

Authors: (CHEN; CHENG, 2012)

Title: Factors affecting the knowledge sharing attitude of hotel service personnel

Authors: (CHEN et al., 2012)

Title: A review of the literature on culture in hotel management research: what is the future?

Authors: (HON, 2012)

When competency-based pay relates to creative

Title: performance: the moderating role of employee psychological need

Article

Qualitative

Restaurant

Article

Quantitative

Hotels

Review

$\begin{array}{llc}\text { Article } & \text { Quantitative } & \begin{array}{c}\text { Hotels and } \\ \text { Services }\end{array} \\ \text { Article } & \text { Qualitative } & \text { Hotels }\end{array}$

Authors: (YANG, 2012)

Title: Effects of ownership change on organizational settings and strategies in a Taiwanese hotel chain

Authors: (RUETZLER; TAYLOR; REYNOLDS; BAKER, 2011)

Title: Understanding perceptions of professional attributes using conjoint analysis

Authors: (DAWSON; ABBOTT; SHOEMAKER, 2011)

Title: The hospitality culture scale: a measure organizational culture and personal attributes

Authors: (GJERALD; OGAARD, 2010a)

Eliciting and analyzing the basic assumptions of

Title: hospitality employees about guests, co-workers, and competitors

Authors: (UBEDA-GARCIA et al., 2018)

Continuous innovation in the hotel industry the development of

Title: organizational ambidexterity through human capital and organizational culture in Spanish hotels

Authors: (LAW et al., 2018)

Article

Mixed

Hotels and

Title: Systematic review of hospitality CRM research

Authors: (YOUN, KIM; SONG, 2017)

Article

Quantitative

Hotels

Title: The leading causes and consequences of citizenship pressure in the hotel industry

Authors: (RAHIMI, 2017)

Article

Quantitative

Hotels

Customer relationship management (people, process and

Title: technology) and organizational culture in hotels which traits matter?

Authors: (RAHIMI; GUNLU, 2016)

Article

Quantitative

Hotels

Implementing customer relationship management (CRM) in hotel

Title: industry from organizational culture perspective case of a chain hotel in the UK

Authors: (QIN et al., 2015)

Article

Qualitative

Hotels

Title: 7 Days Inn

Authors: (KARATEPE, 2013) 
ISSN: 2236-269X

DOI: 10.14807/ijmp.v11i4.1089

The effects of work overload and work-family conflict on job

Title: embeddedness and job performance the mediation of emotional exhaustion

Authors: (O'NEILL, 2012a)

Article

The determinants of a culture of partying among managers in the

Title: hotel industry

Authors: (ASREE, ZAIN; RAZALLI, 2010)

Title: Influence of leadership competency and organizational culture on

Authors: (GJERALD; OGAARD, 2010)

Exploring the measurement of basic assumptions about guests and co-workers in the hospitality industry

Authors: (BELLOU; ANDRONIKIDIS, 2009)

Examining organizational climate in greek hotels from a service quality perspective

Authors: (SIMONS, PARKS; TOMLINSON, 2018).

The benefits of walking your talk: aggregate effects of

Title: behavioral integrity on guest satisfaction, turnover, and hotel profitability

Authors: (HAN, 2012)

Title:

The relationship among corporate culture, strategic orientation, and financial performance

Article

Quantitative

Hotels

Authors: (HON; LEUNG,2011)

Title: Employee creativity and motivation in the Chinese context the moderating role of organizational culture

Article

Authors: (BAKER; HASTINGS, 2016)

Title: "Texting In Their Pockets": Millennials And Rule Violations in the Hospitality Industry

Authors: (ZHAO et al., 2016)

Title:

Motivating Frontline Employees: Role of Job Characteristics in Work and Life Satisfaction

Authors: (O'NEILL, 2012b)
Quantitative

Article

Quantitative

Hotels

Article

Quantitative

Restaurants

Article

Qualitative

Electronic services, sales and marketing services, and hotels

Hotels

theme parks, hotels and visitor information centers

Article Quantitative

Hotels

Quantitative Hotels 
DOI: 10.14807/ijmp.v11i4.1089

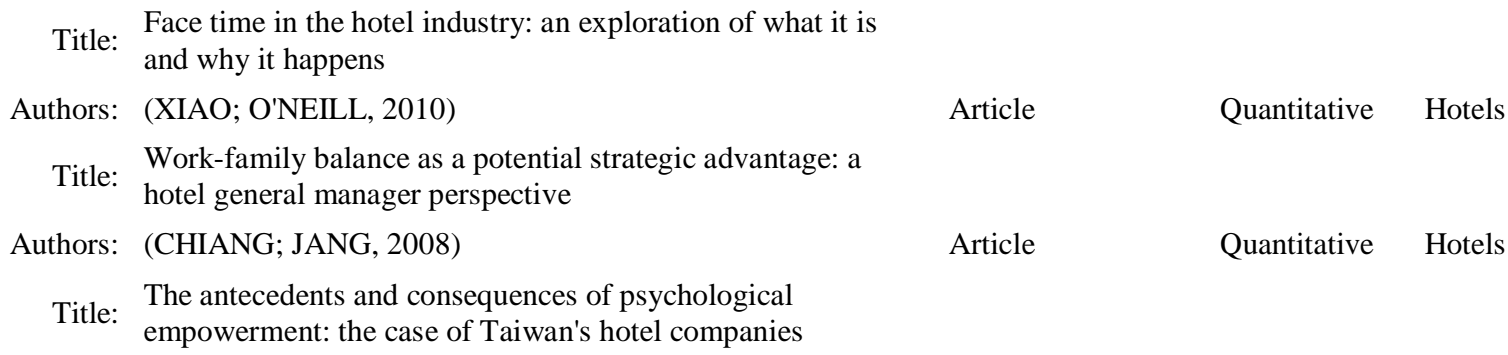

Title: Work-family balance as a potential strategic advantage: a hotel general manager perspective

Authors: (CHIANG; JANG, 2008)

Article

Quantitative Hotels

Title: The antecedents and consequences of psychological empowerment: the case of Taiwan's hotel companies

\subsection{Co-occurrence of keywords}

The purpose of this indicator is that when words frequently co-occur in documents, it means that the concepts behind those words are closely related to (ZUPIC; CATER, 2015). The co-words analysis made it possible to obtain two types of results: (1) the definition of the themes present in the field and their classification within the strategic matrix in terms of their different levels of development; and (2) networks of keywords associated with each thematic cluster (LOPEZ-FERNANDEZ; SERRANO-BEDIA; PEREZ-PEREZ, 2016).

The 43 analyzed publications contain 176 defined keywords by the authors of the publications. The analysis of co-occurrence of keywords shown than 16 keywords presented co-occurrence in the least two times. In table 3 are shown the keywords of authors and their number of occurrences. The word "Hotel" is present in four keywords (Hotels, Hotel employee, Hotel Management, and Hotel Industry). The keyword "restaurants" in only one keyword. "Performance" is a critical keyword linked to organizational culture, and it has two cooccurrences in the analyzed publications. At last, Leadership has six occurrences. Figure 2 shows the network map of Keywords of authors.

Table 3: Key Words by author

\begin{tabular}{lcclcc}
\hline Keyword & OCC & TLS & Keyword & OCC & TLS \\
\hline organizational culture & 23 & 23 & human resources management & 2 & 2 \\
Leadership & 6 & 9 & internal marketing & 2 & 3 \\
Hotels & 4 & 4 & job satisfaction & 2 & 4 \\
hotel employees & 3 & 4 & job stress & 2 & 3 \\
hotel management & 3 & 2 & new zealand & 2 & 1 \\
customer relationship management & 2 & 2 & Performance & 2 & 1 \\
customer satisfaction & 2 & 2 & Restaurants & 2 & 2 \\
hotel industry & 2 & 3 & Trust & 2 & 5 \\
\hline
\end{tabular}




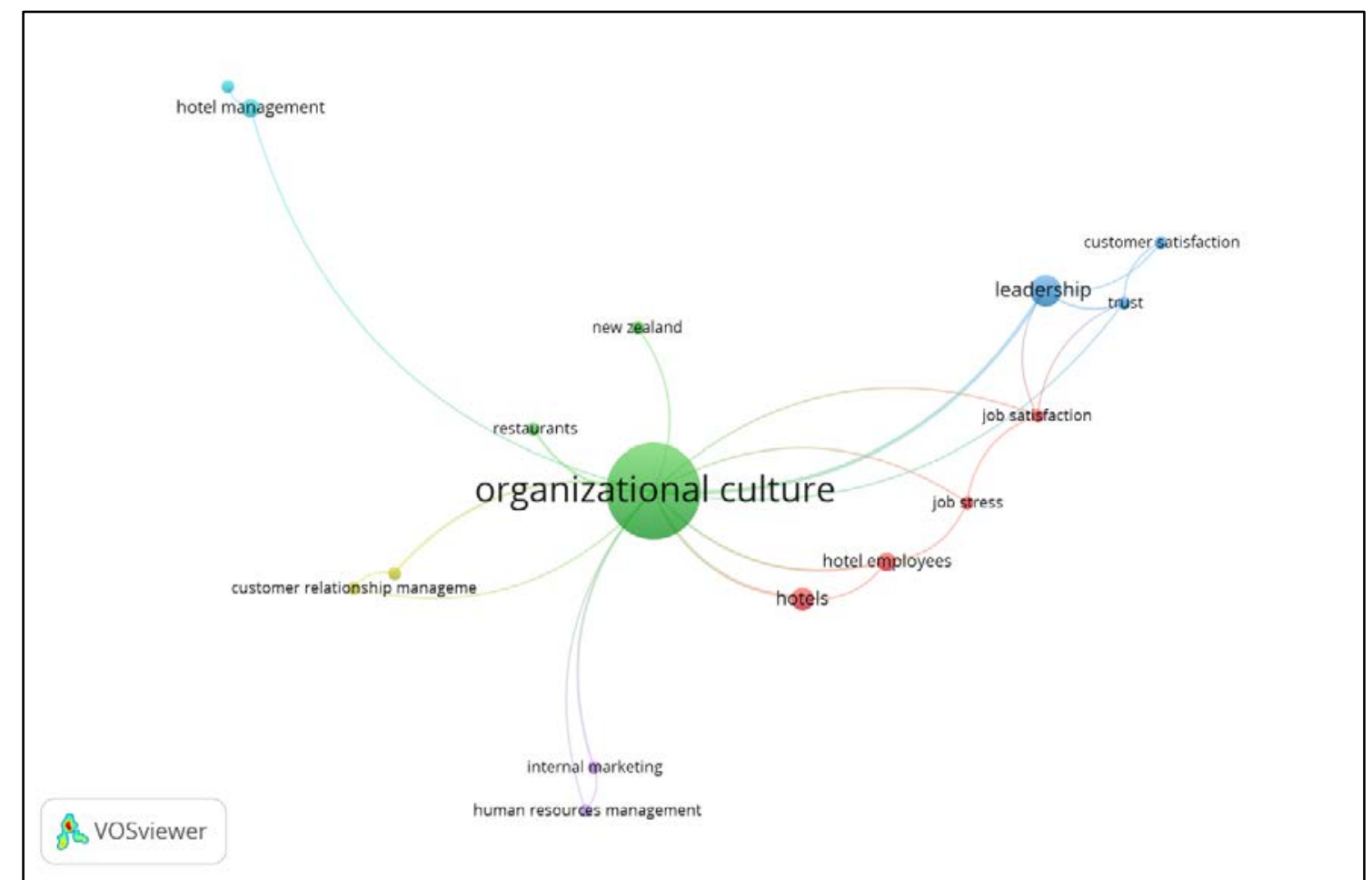

Figure 2: Network map of Key words of authors in publications of five main journals in Hospitality 1980-2019

\subsection{Bibliographic Coupling}

The analysis of bibliographic coupling is shown in figure 3. Here, the network map permits to identify the cluster and relationship between the authors about the topic. This analysis is performed to show lines of future research because it includes recent publications about the topic.

As shown, the research in organizational culture is divided into three clusters (figure 3). The first one (in red), contains publications on topics related to the OC that can be used as usual strategies to improve performance. The second (in green) is related to topics on OC that are used to build specific strategies in Hospitality Management. Finally, the third cluster (in blue) is focused on Customer Relation Management and OC. It thus contains most of the publications using quantitative methodologies. 
DOI: 10.14807/ijmp.v11i4.1089

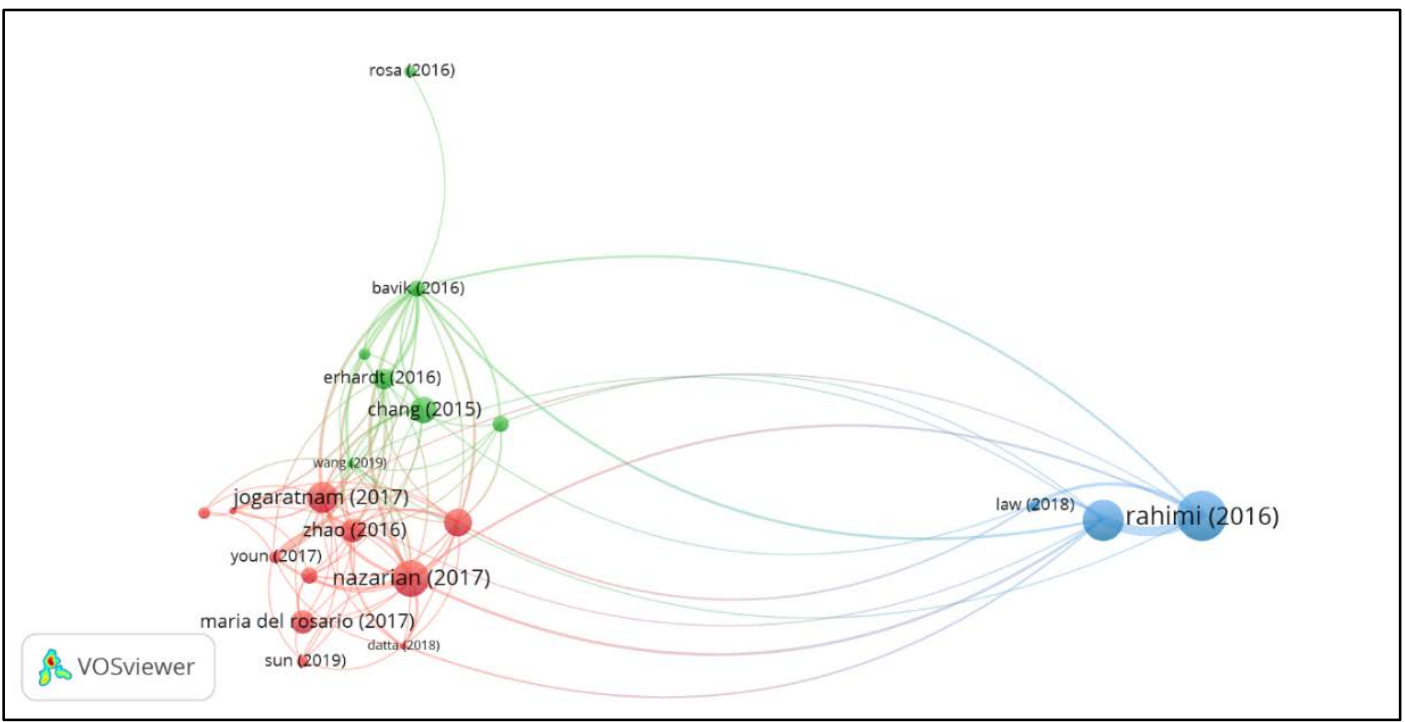

Figure 3: Bibliographic coupling of publications on organizational culture in five journals of hospitality

1980-2019

\subsection{Systematic Literature Review}

The bibliometric analysis identified three clusters that include publications with the relation between them. Then, after a analyzes process, the clusters were named (red) OC and Common Strategies in Hospitality Management, (green)OC and Specific Strategies in Hospitality Management, and (blue) OC and CRM Strategic for Hospitality Management.

\subsubsection{Red Cluster. OC and Common strategies in hospitality Industry.}

This cluster incorporates publications that focus on strategies of management between OC and another topic to improve the performance in hospitality management. Eleven publications integrate the cluster, focusing on variables that may affect outcomes such as performance and others. Identifies the variables aforementioned and applicate strategies for improving the outcomes is the central challenge.

Out of eleven publications, nine were done using a quantitative methodology and two for qualitative methodology. Hotels were the enterprise more used to develop the researches, while only one restaurant was used as the place where the research was developed. These researches were done in diverse countries: (3) US, (3) China (1) Spain, (1) India, (1) UK, (1) Taiwan and (1) México.

In the red cluster, there is a group of publication with focus on the performance Jogaratnam (2017), Simons et al. (2018), Ubeda-Garcia et al. (2018) and Nazarian et al. (2017). In this research, Jogaratnam (2017) showed in the specific area of the hospitality industry of restaurants, the relationship between OC, market orientation with performance. Here, 
DOI: 10.14807/ijmp.v11i4.1089

Jogaratnam confirms that some types of organizational culture are better predictors of performance than market orientation.

In another side, Nazarian et al. (2017) explain in his publication how in London's hotels, the performance is improved through of development of a balanced organizational culture in the enterprise, and that for this is necessary to take into the specific influence of the national culture of the host country.

Ubeda-Garcia et al. (2018) used a sample of 100 hotels in Spain to determine whether the use of high-performance work systems (HPWSs) facilitates the development of organizational ambidexterity directly, or if the organizational ambidextrous culture serves as mediating variable. Organizational ambidexterity is the ability of organizations to use their current competencies and at the same time, to explore new opportunities for the improvement of new capabilities.

In conclusion, Ubeda-Garcia et al. (2018) confirm that HPWSs exert a direct influence on organizational ambidexterity and ambidextrous organizational culture emerges as a mediating variable between HPWSs and organizational ambidexterity. The ambidexterity presents an impact on the performance of hotels.

Finally, Simons et al. (2018) in their study of US hotels analyzed the association between the behavior integrity of managers and worker turnover, customer satisfaction, and hotel profitability. They used in their research a sample constituted by workers of hotels of the same brand, and they determined the presence of a strong association between the variables in the study.

Another identified group in this cluster (red) is a group of publications with a selective approach on psychological issues of workers Datta; Singh (2018), Zhao et al. (2016) and Youn et al. (2017). In the first place,Datta and Singh (2018) studied the climate perceived by hospitality employees in luxury hotels in India, and they specified four dimensions of climate: "esprit of profession, organization, and workgroup"; "leader facilitation and support"; "cohesion, clarity and objectivity of system" and "job challenge, variety and feedback".

In another way, Zhao et al. (2016) examined the intrinsic motivation for hospitality jobs and the effects of job characteristics (skill variety, task identity, task significance, autonomy, feedback on job satisfaction, job stress, and life satisfaction in hotels of China and their findings suggested management strategies for enriching hospitality jobs and intrinsically motivating frontline employees. 
DOI: 10.14807/ijmp.v11i4.1089

Finally, Youn et al. (2017) in their research in China, collected for hotel employees' information about citizenship pressure, personality, organizational culture, job stress, and intention to quit. They argue that neurotic employees are likely to experience citizenship pressure, and citizenship pressure was found to increase job stress and turnover intentions. By last, a bureaucratic culture that prizes stability reduce citizenship pressure.

A third group focus in this cluster (red) is an integer by Sun et al. (2019), ReyesSantiago et al. (2017), Kao et al. (2016) and Qin et al. (2015) who present different topics related to improving performance, but it is necessary to develop an adequate organizational culture for their correct implementation in the enterprise.

Reyes-Santiago et al. (2017) analyzed the relationship between organizational culture and eco-innovation in hotels in México. They found the presence of eco-innovation take into adhocracy culture and organization size. Moreover, they argue that the implications of their results for enterprise tend towards the convenience of adopting an adhocracy culture because this culture facilitates the implementation of eco-innovation at different levels and potentiates both environmental and organizational results.

Kao et al. (2016) developed a framework about customer delight culture in the hospitality industry. Through qualitative research, Kao et al. used in-deep interviews with senior hotel executives and managers in Taiwan. They argue that from cultural perspectives, this study revealed the interrelationships among cultural domains (values, norms, artifacts, and behaviors) in organizations to create customer delight.

Qin et al. (2015) studied an enterprise of the hospitality industry in China. They choose a specific brand hotel to do a case of study because this hotel has some management innovations. In his research, Qin et al. identified seven significant innovative management practices developed by the hotel in the study.

Sun et al. (2019) argue that the impacts of cultural value on technology adoption at the individual level have not been explored, and in the study researched the impacts of cultural values on technology acceptance at the individual level. Sun et al. (2019) used a questionnaire to collect data from hotel employees currently working in the hotel industry in the U.S. In their findings; Sun et al. affirm that the enterprise has created a different approach to think about the fundamental issues regarding business and management that constituted cornerstones of its management innovations.

\subsubsection{Green cluster. OC and specifics strategies in hospitality Industry.}


DOI: 10.14807/ijmp.v11i4.1089

This cluster has some peculiarities and diverse topics (employee brand love, servicescape hospitality culture, millennials and violations rules, workplace rituals, organizational culture in the hospitality industry, service brand value, and others). The name for this cluster is OC and specific strategies in the hospitality industry because it adds research topics of high interest to the practitioners of this industry, topics that would aid them to improve hospitality management.

This cluster is integrated by seven publications of different types, five articles, one review, and one editorial note. The research approach is diverse too; three publication was developed using qualitative approach, one publication was done using a quantitative approach, one publication was done using a mixed approach, one publication is a review of the literature, and the last one is an editorial note.

Analyzing by type of publication, the publications of Baker; Hastings (2016), Erhardt et al. (2016), and Chang; Ma (2015) were performed and analysis based on the methodology used by the researcher. Through of interviews to Total Management Team (TMT) leaders in the hotel at China, Chang et al. (2015) explores how a hotel uses its resource-based advantages (service brand value, TMT leadership, and others) to atone for institutional constraints, while at the same time complementing these resource-based advantages with institutional advantages, therefore its sustainable competitive advantages growing, this in emerging market.

Erhardt et al. (2016) did a study within restaurants enterprises in the US, where they identify and unpack eight employee-focused emotional, behavioral, and cognitive workplace rituals linked with owners' core values such as comradery, creativity, competition and efficiency and they argue that workplace rituals are active learning mechanisms for core values that underpin organizational culture in restaurants. Baker and Hastings (2016) did interviews with twenty-five managers in the hospitality industry to learn about their perceptions of millennial employees.

Baker et al. (2016) examined only three categories of organizational rules (policies regarding cell phone use, policies regarding requesting time off, and civility) and was evident that collective millennial generational affected rules and the culture of the organization.

Wang et al. (2019) in their quantitative research in a hotel in the US and Taiwan analyzed in this study OC and loving behaviors. They propose that forgiveness behavior, supportive voice behavior, and helping behavior improved through employee brand love. Also, 
INDEPENDENT JOURNAL OF MANAGEMENT \& PRODUCTION (IJM\&P)

http://www.ijmp.jor.br

v. 11, n. 4, July - August 2020

ISSN: 2236-269X

DOI: 10.14807/ijmp.v11i4.1089

Wang et al. (2019) argue that OC moderates the relationship between brand love and love behaviors.

In another side, Bavik (2016a) purposes in their study identified in the hospitality industry the dimensions that add organizational culture and investigate whether the identified dimensions are specific and unique to other industries. Babik (2016) argues that the hospitality industry has unique cultural characteristics that are distinguished from similar industries and affirm that cohesiveness is the most important cultural element of the hospitality industry.

Pizam (2018) have two publications in this cluster. the first one is an editorial note where defined hospitality as "an organizational culture that permeates throughout the entire organization and makes it what it is", also defined hospitality culture as "a system of shared norms, values, beliefs, traditions, and expectations whose ultimate goal is to provide exceptional service and memorable experiences to all the organization's stakeholders (p:III).”

Pizam proposed thirteen characteristics of hospitality culture and affirmed that hospitality organizational cultures could be practiced by all service organizations and even manufacturing enterprises. Pizam and Tasci (2019) built an analysis of the literature on servicescape and relevant concepts. The review of the literature produced a term denominated "experienscape" that is enhanced with the OC of hospitality and the incorporation of employees, as both internal customers and service providers, as well as other stakeholders

\subsubsection{Blue cluster: Custom Relationship Management in the Hospitality Industry}

This cluster is the smallest of the three clusters of this analysis. It includes three publications: One review of the literature and two articles with a quantitative approach, all them with relationship about Customer Relation Management.

Law et al. (2018) realized a comprehensively and systematically review the state of customer relationship management (CRM) research on hospitality and propose a future research agenda. Law et al. (2018) conclude in their review affirming than Hospitality CRM research has rapidly grown from the initial relationship marketing concept into social CRM and their identified five lines for future research: planning and implementation process, organizational support, technology and tools, customer perspectives and characteristics, and outcome and impact.

Rahimi and Gunlu (2016) researched chain hotel from the UK, where they applied a survey to managers to identified impacts of organizational cultures of consistency, adaptability, mission, and involvement on CRM implementation. Some factors of organizational culture 
DOI: 10.14807/ijmp.v11i4.1089

(adaptability, consistency, staff involvement and mission, and vision) of the organization have a significant positive impact on CRM implementation.

Rahimi (2017) examine the impact of organizational culture on the three components of customer relationship management (people, process, and technology) in the hotel industry. Rahimi (2017) used a questionnaire that distributed among 364 managers of a chain hotel in the UK and revealed that the four traits adaptability, consistency, involvement and mission have positive and significant impacts on the three components of CRM.

\section{CONCLUSIONS}

This article constitutes the first attempt to show an objective review of academic research on organizational culture in hospitality industry applying bibliometric indicators such as co-occurrence analysis of keywords and bibliographic coupling. It uses as a basis the publications of five particular journals on hospitality on the Web of Science Core Collection database. Several conclusions spring from the analysis.

Organizational culture in the hospitality industry has been related to topics such as leadership, performance, total quality service, customer delight, and customer service. Hotels are the primary context where the researches of organizational culture are done. A minor proportion of researches are done in restaurants.

Leadership is considered an essential topic for the implantation of organizational culture. Customer relationship management, customer satisfaction are strategies for improving performance in hospitality management; these strategies on adequate organizational culture will able to be successful.

The bibliometric analysis resulted in three distinct clusters: 1 (red) OC and Common Strategies in Hospitality Management, 2 (green) OC and Specific Strategies in Hospitality Management 3 (blue) OC and CRM Strategic for Hospitality Management. These three clusters allowed to identify three ways for where the research in OC in the hospitality industry has developed nowadays.

First, some publications have a focus on strategies of management between OC and other topics to improve the performance in hospitality management. Eleven publications integrated the cluster, where the focus is variables that may affect outcomes such as performance. In this group, to identify the variables and to apply strategies for improving the outputs is the central challenge. 
DOI: 10.14807/ijmp.v11i4.1089

Second, a group that includes diverse novel topics (employee brand love, servicescape hospitality culture, millennials and violations rules, workplace rituals, organizational culture in the hospitality industry, service brand value, and others). This group adds topics of high interest to the practitioners of this industry, topics that could aid them to improve hospitality management.

Third, a small group where the focus is Customer Relation Management. Here, this topic is studied as a strategy for improving the outputs of enterprise hospitality.

By last, possible research gaps in the organizational culture in the hospitality industry would include:

1) In the hospitality industry, restaurant companies present scarce research about OC and its relationship with some other topics. Increasing the research in this context will allow using OC as a strategy for improving outputs of the enterprises.

2) The quantitative approach is the most used methodology for the researchers. The scope of use to Qualitative approach will give the practitioners an in-depth knowledge of features of OC, and it would able be used as a competitive advantage.

3) It was not found a measurement instrument for assessment OC in restaurants; the attempts of developing a scale have been made in hotels.

\section{REFERENCES}

ASREE, S.; ZAIN, M.; RAZALLI, M. R. (2010) Influence of leadership competency and organizational culture on responsiveness and performance of firms. International Journal of Contemporary Hospitality Management, n. 22, p. 500-516.

AZIC, M. L. (2017) The impact of hotel employee satisfaction on hospitability performance. Tourism and Hospitality Management-Croatia, n. 23, p. 105-117.

BAKER, R. N.; HASTINGS, S. O. (2016) Texting in their pockets: Millennials and rule violations in the hospitality industry. Journal of Hospitality and Tourism Management, $n$. 29, p. 33-40.

BARROWS, C. W.; POWERS, T.; REYNOLDS, D. (2012) Introduction to the hospitality industry, 8 ed. Hoboken, New Jersey: John Wiley \& Sons, I.

BAVIK, A. (2016a) Developing a new hospitality industry organizational culture scale.

International Journal of Hospitality Management, n. 58, p. 44-55.

BAVIK, A. (2016b) Identification of organizational culture in the hospitality industry. In: KOZAK, M.; KOZAK, N. (eds.) Tourism and Hospitality Management. Bingley: Emerald Group Publishing Ltd. p. 197-210. 
BELLOU, V.; ANDRONIKIDIS, A. I. (2009) Examining organizational climate in Greek hotels from a service quality perspective. International Journal of Contemporary Hospitality Management, n. 21, p. 294-307.

BROWNELL, J. (2008) A commentary on "Leading change with the 5-P Model: 'Complexing' the Swan and Dolphin Hotels at Walt Disney World. Cornell Hospitality Quarterly, n. 49, p. 206-210.

CAPUTO, A.; MARZI, G.; PELLEGRINI, M. M.; RIALTI, R. (2018) Conflict management in family businesses: A bibliometric analysis and systematic literature review. International Journal of Conflict Management, v. 29, n. 4, p. 519-542.

CHANG, H. P.; MA, C. C. (2015). Managing the service brand value of the hotel industry in an emerging market. International Journal of Hospitality Management, n. 47, p. 1-13.

CHEN, R. X. Y.; CHEUNG, C.; LAW, R. (2012) A review of the literature on culture in hotel management research: What is the future? International Journal of Hospitality Management, n. 31, p. 52-65.

CHEN, W. J. (2013) Factors influencing internal service quality at international tourist hotels. International Journal of Hospitality Management, n. 35, p. 152-160.

CHEN, W. J.; CHENG, H. Y. (2012) Factors affecting the knowledge sharing attitude of hotel service personnel. International Journal of Hospitality Management, n. 31, p. 468476.

CHIANG, C. F.; JANG, S. (2008) The antecedents and consequences of psychological empowerment: the case of Taiwan's hotel companies. Journal of Hospitality \& Tourism Research, n. 32, p. 40-61.

CHOUDHURY, N.; MCINTOSH, A. (2013) Retaining students as employees: Owner operated small hospitality businesses in a university town in New Zealand. International Journal of Hospitality Management, n. 32, p. 261-269.

DATTA, A.; SINGH, R. (2018) Determining the dimensions of organizational climate perceived by the hotel employees. Journal of Hospitality and Tourism Management, $\mathrm{n}$. 36, p. 40-48.

DAWSON, M.; ABBOTT, J.; SHOEMAKER, S. (2011) The Hospitality Culture Scale: A measure organizational culture and personal attributes. International Journal of Hospitality Management, n. 30, p. 290-300.

ERHARDT, N.; MARTIN-RIOS, C.; HECKSCHER, C. (2016) Am I doing the right thing? Unpacking workplace rituals as mechanisms for strong organizational culture. International Journal of Hospitality Management, n. 59, p. 31-41.

GJERALD, O.; OGAARD, T. (2010) Exploring the measurement of basic assumptions about guests and co-workers in the hospitality industry. International Journal of Contemporary Hospitality Management, n. 22, p. 887-909.

GJURASIC, M.; LONCARIC, D. (2018) Internal market orientation and organizational citizenship behavior in the hospitality industry - a literature review. Ekonomska Misao I Praksa-Economic Thought and Practice, n. 27, p. 157-176.

HAN, H. (2012) The Relationship among Corporate Culture, Strategic Orientation, and Financial Performance. Cornell Hospitality Quarterly, n. 53, p. 207-219. 
HON, A. H. Y. (2012) When competency-based pay relates to creative performance: The moderating role of employee psychological need. International Journal of Hospitality Management, n. 31, p. 130-138.

HON, A. H. Y.; LEUNG, A. S. M. (2011) Employee Creativity and Motivation in the Chinese Context: The Moderating Role of Organizational Culture. Cornell Hospitality Quarterly, n. 52, p. 125-134.

HUANG, J.; LI, W. W.; QIU, C. H.; YIM, F. H. K.; WAN, J. B. (2016) The impact of CEO servant leadership on firm performance in the hospitality industry. International Journal of Contemporary Hospitality Management, n. 28, p. 945-968.

JOGARATNAM, G. (2017) How organizational culture influences market orientation and business performance in the restaurant industry. Journal of Hospitality and Tourism Management, n. 31, p. 211-219.

KAO, C. Y.; TSAUR, S. H.; WU, T. C. (2016) Organizational culture on customer delight in the hospitality industry. International Journal of Hospitality Management, n. 56, p. 98108.

KARATEPE, O. M. (2013) The effects of work overload and work-family conflict on job embeddedness and job performance The mediation of emotional exhaustion. International Journal of Contemporary Hospitality Management, n. 25, p. 614-634.

KASEMSAP, K.; SOOD, T. (2017) Promoting Service Innovation and Knowledge Management in the Hospitality Industry, Hersey, Igi Global, p. 243-279.

KIM, M.; VOGT, C. A.; KNUTSON, B. J. (2015) Relationships among customer satisfaction, delight, and loyalty in the hospitality industry. Journal of Hospitality \& Tourism Research, n. 39, p. 170-197.

KRUJA, D.; HA, H.; DRISHTI, E.; OELFKE, T. (2016) Empowerment in the Hospitality Industry in the United States. Journal of Hospitality Marketing \& Management, n. 25, p. 25-48.

KUSLUVAN, S.; KUSLUVAN, Z.; ILHAN, I.; BUYRUK, L. (2010) The Human Dimension A Review of Human Resources Management Issues in the Tourism and Hospitality Industry. Cornell Hospitality Quarterly, n. 51, p. 171-214.

LAW, R.; FONG, D. K. C.; CHAN, I. C. C.; FONG, L. H. N. (2018) Systematic review of hospitality CRM research. International Journal of Contemporary Hospitality Management, n. 30, p. 1686-1704.

LEYVA-DUARTE, J. E.; CHAVEZ, J. J.; PINEDO-DE-ANDA, F. J.; NIEBLA, J. C. (2019) Bibliometric analysis of Organizational culture in Business economics of Web of Science, 1980-2018. Nova Scientia, v. 11, n. 22, p. 478-500.

LOPEZ-FERNANDEZ, M. C.; SERRANO-BEDIA, A. M.; PEREZ-PEREZ, M. (2016)

Entrepreneurship and Family Firm Research: A Bibliometric Analysis of An Emerging Field. Journal of Small Business Management, n. 54, p. 622-639.

MASCARENHAS, C.; MARQUES, C. S.; GALVAO, A. R.; SANTOS, G. (2017). Entrepreneurial university: towards a better understanding of past trends and future directions. Journal of Enterprising Communities-People and Places of Global Economy, v. 11, n. 3, p. 316-338. 
NAZARIAN, A.; ATKINSON, P.; FOROUDI, P. (2017) Influence of national culture and balanced organizational culture on the hotel industry's performance. International Journal of Hospitality Management, n. 63, p. 22-32.

O'NEILL, J. W. (2012a) The determinants of a culture of partying among managers in the hotel industry. International Journal of Contemporary Hospitality Management, n. 24, p. 81-96.

O'NEILL, J. W. (2012b) Face time in the hotel industry: an exploration of what it is and why it happens. Journal of Hospitality \& Tourism Research, n. 36, p. 478-494.

PIZAM, A. (2009) What is the hospitality industry and how does it differ from the tourism and travel industries? International Journal of Hospitality Management, n. 28, p. 183-184.

PIZAM, A. (2018) Hospitality as an Organizational Culture. International Journal of Hospitality Management, n. 71, p. III-III.

QIN, Y.; LI, B.; YU, L. (2015) Management innovations in a Chinese hotel company: the case of 7 Days Inn. International Journal of Contemporary Hospitality Management, $\mathrm{n}$. 27, p. 1856-1880.

RAHIMI, R. (2017) Customer relationship management (people, process and technology) and organizational culture in hotels Which traits matter? International Journal of Contemporary Hospitality Management, n. 29, p. 1380-1402.

RAHIMI, R.; GUNLU, E. (2016) Implementing Customer Relationship Management (CRM) in hotel industry from organizational culture perspective Case of a chain hotel in the UK. International Journal of Contemporary Hospitality Management, n. 28, p. 89-112.

REYES-SANTIAGO, M. R.; SÁNCHEZ-MEDINA, P. S.; DÍAZ-PICHARDO, R. (2017) Eco-innovation and organizational culture in the hotel industry. International Journal of Hospitality Management, n. 65, p. 71-80.

SIMONS, T.; PARKS, J. M.; TOMLINSON, E. C. (2018) The Benefits of Walking Your Talk: Aggregate Effects of Behavioral Integrity on Guest Satisfaction, Turnover, and Hotel Profitability. Cornell Hospitality Quarterly, n. 59, p. 257-274.

SINGH, R. (2015) Empirical Examination of the Impact of Total Quality Services on Hospitality Industry Business. Journal of Quality Assurance in Hospitality \& Tourism, n. 16, p. 389-413.

SUN, S.; LEE, P.; LAW, R. (2019) Impact of cultural values on technology acceptance and technology readiness. International Journal of Hospitality Management, n. 77, p. 89-96.

UBEDA-GARCIA, M.; CLAVER-CORTES, E.; MARCO-LAJARA, B.; GARCIA-LILLO, F.; ZARAGOZA-SAEZ, P. C. (2018) Continuous innovation in the hotel industry The development of organizational ambidexterity through human capital and organizational culture in Spanish hotels. International Journal of Contemporary Hospitality Management, n. 30, p. 3609-3631.

VAN ECK, N. J.; WALTMAN, L. (2010) Software survey: VOSviewer, a computer program for bibliometric mapping. Scientometrics, p. 84, p. 523-538.

WANG, Y. C.; RYAN, B.; YANG, C. E. (2019) Employee brand love and love behaviors: Perspectives of social exchange and rational choice. International Journal of Hospitality Management, n. 77, p. 458-467. 
XIAO, Q.; O'NEILL, J. W. (2010) Work-family balance as a potential strategic advantage: a hotel general manager perspective. Journal of Hospitality \& Tourism Research, n. 34, p. 415-439.

YANG, J. T. (2012) Effects of ownership change on organizational settings and strategies in a Taiwanese hotel chain. International Journal of Hospitality Management, n. 31, p. 428441.

YOUN, H.; KIM, J. H.; SONG, H. Q. (2017) The leading causes and consequences of citizenship pressure in the hotel industry. International Journal of Contemporary Hospitality Management, n. 29, p. 1541-1559.

ZHAO, X. Y.; GHISELLI, R.; LAW, R.; MA, J. (2016) Motivating frontline employees: Role of job characteristics in work and life satisfaction. Journal of Hospitality and Tourism Management, n. 27, p. 27-38.

ZUPIC, I.; CATER, T. (2015) Bibliometric Methods in Management and Organization. Organizational Research Methods, n. 18, p. 429-472. 